Foytl, J., Chisholm, F. and Varsou, O. (2020) Sharps injuries during dissection: a five-year retrospective study in the context of safety. Anatomical Sciences Education, 13, pp. 158-167.

There may be differences between this version and the published version. You are advised to consult the publisher's version if you wish to cite from it.

This is the peer reviewed version of the following article:

Foytl, J., Chisholm, F. and Varsou, O. (2020) Sharps injuries during dissection: a five-year retrospective study in the context of safety. Anatomical Sciences Education, 13, pp. 158-167. (doi: 10.1002/ase.1894)

This article may be used for non-commercial purposes in accordance with Wiley Terms and Conditions for Self-Archiving.

http://eprints.gla.ac.uk/186590/

Deposited on: 14 May 2019

Enlighten - Research publications by members of the University of Glasgow http://eprints.gla.ac.uk/ 
ASE-18-0254.R1

Research Report

\title{
Sharps Injuries During Dissection: A Five-year Retrospective Study in the Context of Safety
}

\author{
Jakub Foytl, ${ }^{1,2}$ Fraser Chisholm, ${ }^{2}$ Ourania $\operatorname{Varsou}^{2,3, *}$ \\ ${ }^{1}$ School of Medicine, Dentistry and Nursing, University of Glasgow, Scotland United Kingdom \\ ${ }^{2}$ School of Medicine, University of St Andrews, North Haugh, St Andrews, Scotland, United \\ Kingdom \\ ${ }^{3}$ Anatomy Facility, School of Life Sciences, University of Glasgow, Glasgow, Scotland, United \\ Kingdom
}

Running title: Sharps Injuries During Dissection

*Correspondence to: Dr Ourania Varsou, Anatomy Facility, School of Life Sciences, University of Glasgow, Thomson Building, University Avenue, Glasgow G12 8QQ, Scotland. UK. E-mail: o.varsou@googlemail.com 


\section{ABSTRACT}

The supplementation of lecture-based anatomy teaching with laboratory sessions, involving dissection or anatomical specimens, is commonly used. Hands-on dissection allows students to handle instruments correctly while actively exploring three-dimensional anatomy. However, dissection carries a potential risk of sharps and splash injuries. The aim of this study was to quantify the frequency rate of such cases per 1,000 student-hours of dissection and identify potential factors than might influence safety in anatomy laboratories. Data were retrospectively collected from September 2013 to June 2018 at the University of St Andrews, Scotland UK. Overall, 35 sharps injuries were recorded in undergraduate medical students, with a frequency rate of 0.384 and no splash cases. A statistically significant, moderate negative association between year of study and frequency rate $(\operatorname{rho}(25)=-0.663 ; P<0.001)$ was noted. A statistically significant difference in the frequency rate between different semester modules $\left(\chi^{2}(4)=13.577\right.$, $P=0.009)$ was observed with the difference being between year 1 semester 2 and year 3 semester $1(P=0.004)$. The decreasing trend with advancing year of study might be linked to increasing dissecting experience or the surface area of the region dissected. The following factors might have contributed to increased safety influencing frequency rates: single-handed blade removal systems; mandatory personal protective equipment; and having only one student dissecting at a given time. The authors propose that safety familiarization alongside standardized training and safety measures, as part of an evidence-based culture shift, will instill safety conscious behaviors and reduce injuries in anatomy laboratories.

Key words: gross anatomy education, medical education, undergraduate education, cadaver dissection, anatomy laboratory, dissection room, sharps injuries, splash injuries, training 


\section{INTRODUCTION}

A sound knowledge and understanding of human anatomy is essential for all healthcare professionals and aspiring anatomists. Higher education institutions supplement lecture-based, didactic teaching of anatomy with laboratory sessions either in the form of cadaveric dissection and/or review of professionally prepared anatomical specimens (i.e., prosections) (Sargent Jones et al., 2001; Johnson, 2002; Sugand et al., 2010). Dissection provides students with the opportunity to manage human tissue correctly in a simulated surgical environment, introduces them to appropriate handling and use of dissecting instruments (Cornwall and Stringer, 2008; Cornwall et al., 2013) and promotes appreciation of three-dimensional anatomy with the active exploration of structures (Johnson, 2002). Dissection also enhances didactic learning, increases confidence and allows learners to develop essential surgical skills (Johnson, 2002).

Dissection carries potential risks, including that of sharps and splash injuries, which may not be the case in alternative methods including teaching with prosections models and digital approaches such as augmented and virtual reality (Sargent Jones et al., 2001; Johnson, 2002; Cornwall and Stringer, 2008; Cornwall et al., 2013, Shoja et al., 2013). Sharps injuries are incidents in which a sharp object (e.g., needle, blade, human bone) penetrates the skin (HSE, 2018). Splash injuries involve exposure of mucocutaneous membranes (e.g., mouth, eyes, broken skin) to body or wetting/embalming fluids (Chalya et al., 2018). The physical and physiological impact of such injuries can be detrimental especially to undergraduate students (Hambridge et al., 2016). Health and safety practices along with on-going training can mitigate the risk of sharps and splash injuries during dissection in anatomy laboratories and minimize the associated sequelae. 
Anatomy teaching is one of the core elements of the BSc (Honors) in Medicine degree at the University of St Andrews, Scotland UK. Hands-on dissection accompanies the didactic component, which is delivered with anatomy lectures ranging from a minimum of 15 hours (19\%) to a maximum of 24 hours per semester (28\%) with the lowest frequency in the musculoskeletal and cardiorespiratory systems (Table 1). In the anatomy laboratory, students systematically dissect the entire human body of formalin-fixed cadavers, over the course of approximately two and a half years, focusing on a particular anatomical region every semester (Table 1). Dissection classes last typically two hours and take the form of small group teaching with about six to eight students per each cadaver and only one student actively dissecting. An anatomy demonstrator usually supervises two groups. Students use in-house instructions along with atlases to complete a specific dissection. A simulated surgical environment is adopted including: (1) kidney dishes for transferring and storing non-used instruments; (2) accounting for all instruments at the end of class to prevent downstream accidental injuries to technical staff responsible for the maintenance of the laboratory; (3) instruments used only for their intended purpose; and (4) movement within the laboratory kept to a minimum during class. This approach contributes to a 'safe' environment for dissection.

Following the National Health Service (NHS) recommendations on provision of training before exposure to sharps followed by regular refreshers (NHS Employers, 2015), the School of Medicine also adheres to additional training requirements. Before students start dissecting, they have to complete a one-hour compulsory face-to-face training program, introduced in 2013, during which they practise loading removable blades onto scalpels and handling instruments 
correctly (i.e., holding the scalpel in a power and pencil grip and holding the scissors/needle holders using the tripod grip). This is completed under the close supervision of anatomists within the laboratory and it is immediately followed by a one-hour dissection of the superficial back of a cadaver. At the start of the training, students also watch two videos in the laboratory introducing the above topics on how to use and handle instruments following a surgical approach with each video being approximately ten minutes long. Students are expected to re-watch these videos, via the school's virtual learning environment (VLE), at the start of every semester as a 'refresher'. As the videos contain cadaveric material, they are only accessible to staff or students who have signed the Anatomy Code of Conduct. Following an injury, all students and staff are advised to follow the NHS procedure of 'bleed it', 'wash it', 'cover it' and 'report it' with posters mounted in key locations of the anatomy laboratory that also contain details of a local community hospital for out-of-hours advice that applies to faculty members (Sharps Policy, 2019). Students or staff with more than one documented injury are re-trained on the use and handling of sharps with a face-to-face session delivered by one of the academic members of staff.

A strict personal protective equipment (PPE) policy applies to everyone attending the laboratory during dissecting sessions including a laboratory coat, gloves and safety goggles. The eye protection has been adopted on the basis that although splashes incidents of body fluids and formalin are not commonly reported in the literature, they could still cause conjunctival irritation (Mansour et al., 2009; ATSDR, 2018). In addition, the Qlicksmart BladeFLASK single-handed scalpel blade removal system (Swann-Morton Ltd., Sheffield, UK) has been mounted in several assessable stationary points within the anatomy laboratory (Figure 1). These devices have step- 
by-step pictorial instructions and a revolving counter that closes off the aperture after 100 uses. However, it should be stressed that this is only one type of the many different blade removal systems that are currently available and was chosen on the merit that it can be operated by one hand only potentially minimizing injury risk. The general reasoning for installing a safety system is that studies have reported a significant number of injuries occurring while mounting or removing scalpel blades. Cornwall et al. (2013) reported 10\% (15 cases) and Romero-Reveron (2015) 60\% (6 cases) of incidents during this process. To minimize injuries, students are also advised to use kidney dishes to transfer the scalpers to and from the scalpel blade remover devices.

The aim of this study was to quantify the number and frequency rate of documented sharps and splash injuries per 1,000 student-hours of dissection, over a period of five years, and correlate this information with the year of study and semester module to better delineate the relationship between injuries and advancing dissecting experience. A secondary aim was to explore safety precautions to identify potential factors than might influence frequency rate and impact on safety in anatomy laboratories.

\section{MATERIALS AND METHODS}

This was a five-year retrospective study, with records assessed from September 2013 to June 2018, at the University of St Andrews School of Medicine, Scotland, UK. The data collection start date coincided with the introduction of the compulsory training program. During this period, there were no changes relating to the anatomy curriculum or to the health and safety practices that might have confounded reporting and recording attitudes. Two researchers (O.V. 
and F.C.) independently extracted data (i.e., academic year, year of study, type of injury, and mechanism of injury) from the in-house electronic first-aid records that are stored within a secure university drive with controlled staff access. Data were fully anonymized, by removing all identifiable (i.e., names) and demographic (i.e., gender and age) information, to prevent potential re-identification of implicated students. The same researchers then used the school's bespoke Virtual Learning Environment (VLE) (Galen, University of St Andrews School of Medicine, UK) to assign each anonymized case to semester modules and individual teaching sessions based on the date of injury and academic year. The School's VLE was also used to extract the hours of hands-on dissection, excluding all time spent viewing prosections, and student numbers for each academic year allowing for calculation of the frequency rate per 1,000 student-hours of dissection by one of the study researchers (F.C.) following the formula below. Ethical approval was granted by the University of St Andrews School of Medicine Ethics committee (ethics approval code: MD13895).

$$
\text { Frequency rate }=\frac{\text { Number of cases }}{(\text { Number of students } x \text { Dissection hours })} \times 1,000
$$

For the statistical analysis, non-parametric tests were conducted due to the small sample size (<50) and data skewness (Ghasemi and Zhadiesi, 2012). The Spearman's rank correlation coefficient was used to assess for statistical significance along with direction and strength of association between continuous numerical data (i.e., year of study correlated separately with number of documented cases and frequency rate). The Kruskal-Wallis H-test was used to assess for any statistically significant differences in the number of documented cases and frequency rate between different semester modules with asymptotic exact $P$ values reported. Post-hoc analysis 
included the Dunn pairwise test with $P$ values adjusted using the Bonferroni correction $(P<$ 0.05). Data analysis was performed by one of the study researcher (O.V.) in the SPSS statistical package, version 24 (IBM Corp., Armonk, NY).

\section{RESULTS}

A total of 35 cases were recorded from September 2013 to June 2018, representing a frequency rate of 0.384 per 1,000 student-hours of dissection. A decreasing trend between documented cases and increasing year of study was noted, despite the most technically advanced dissection in third year. Twenty eight injuries (80.0\%) representing a frequency rate of 0.692 per 1,000 student-hours were recorded in first year of study, 7 injuries (20.0\%) representing a frequency rate of 0.218 per 1,000 student-hours in second year of study with no documented cases for the third year of study (Table 2). When reviewing each academic year separately, the number of cases ranged from $4(11.4 \%)$ to $10(28.6 \%)$ (Table 3$)$.

All documented cases were classed as sharps injuries, related to skin-penetrating incidents involving dissecting instruments or human bone. The commonest mechanism of injury was by scalpel blade, accounting for 31 (88.6\%) cases. The remaining 4 cases were caused by dissecting scissors (2.9\%), surgical pointers (2.9\%), human bone (2.9\%) and an unknown instrument (2.9\%). Of the recorded total, 29 injuries (82.9\%) were self-inflicted, 5 injuries (14.3\%) were caused by a colleague/peer and 1 injury (2.9\%) had an unknown cause. There were no documented splash cases with mucocutaneous membrane exposure or tissue-projectile cases over the assessed timeframe. 
The number of documented cases and frequency rate decreased with increasing year of study. The Spearman's rank correlation coefficient showed a statistically significant, moderate negative association between year of study and number of cases $(\operatorname{rho}(25)=-0.610 ; P=0.001)$. Similarly, a statistically significant, moderate negative association was noted between the year of study and the frequency rate $(\operatorname{rho}(25)=-0.663 ; P<0.001)$. A Kruskal-Wallis H-test test showed a highly statistically significant difference in the number of documented cases between different semester modules $\left(\chi^{2}(4)=15.743\right.$, asymptotic $\left.P=0.001\right)$ with the mean rank being 11.70 for year 1 semester 1 and year 2 semester 1, 22.90 for year 1 semester 2, 12.70 for year 2 semester 2 , and 6.00 for year 3 semester 1 . Dunn pairwise tests showed a statistically significant difference between year 1 semester 2 and year 3 semester $1(P=0.001$, adjusted by Bonferroni correction). A partial eta squared $\left(\eta^{2}\right)$ of 0.812 indicated a large effect size. Furthermore, a Kruskal-Wallis $\mathrm{H}$ test showed a highly statistically significant difference in the frequency rate between different semesters $\left(\chi^{2}(4)=13.577\right.$, asymptotic $\left.P=0.009\right)$ with the mean rank being 14.20 for year 1 semester 1 (back), 21.90 for year 1 semester $2,11.70$ for year 2 semester $1,11.20$ for year 2 semester 2, and 6.00 for year 3 semester 1 . Dunn pairwise tests showed a statistically significant difference between year 1 semester 2 and year 3 semester $1(P=0.004$, adjusted by the Bonferroni correction). A partial eta squared $\left(\eta^{2} p\right)$ of 0.578 indicated a large effect size.

\section{DISCUSSION}

This study assessed the frequency rate of sharps and splash injury cases in undergraduate medical students during hands-on dissection, over a five-year period utilizing archived first aid records and VLE teaching information, from a single UK higher education institution. 


\section{Comparable Literature}

A comparatively low frequency rate of 0.384 per 1,000 student-hours of dissection was observed amounting to a total of 35 documented sharps injuries. In the context of relevant literature, Cornwall and Stringer (2008) retrospectively analyzed the number and frequency rate of dissecting-room injuries among medical, dental and science students at the University of Otago, New Zealand. The authors reported 55 minor injuries over six years with a rate of less than 4 per 1,000 hours of dissection (Cornwall and Stringer, 2008). In a time-extended but separately disseminated pooled analysis of similar groups from the same anatomy department, Cornwall et al. (2013) reported a total of 163 injuries during eleven years with a frequency rate of 2.87 per 1,000 dissection hours (Cornwall et al., 2013). This difference in injury rates, between the current study and the reported literature, could be partly attributed to the number of students allocated per cadaver and especially the number of students dissecting concurrently. In Cornwall et al. there were 10 medical students per cadaver with two actively dissecting at any given time with the latter also being the case for dental and science students (2013). In the present study, the maximum number of students was eight per cadaver with only one actively dissecting. With an ever-increasing number of students, who have to be accommodated within the same anatomy facilities and within the same allocated teaching hours, it is not unexpected that the density of students per cadaver has increased along with the number of students who dissect concurrently perhaps increasing the risk of injuries. Overall, the above findings highlight that such injuries are not common incidents in anatomy laboratories. However, a small number of these do take place and it is of paramount importance to have mechanisms in place to maximize safety. The authors have discussed some of the main themes that anatomy educationalists may wish to consider when it comes to health and safety in anatomy laboratories. 


\section{Sharps Safety}

Scalpel blades accounted for $88.6 \%$ of cases making these the commonest mechanism of injury. This finding is also reflected in the clinical literature from operating theatres when excluding injuries from needles (Watt et al., 2010) and the educational literature involving anatomy laboratories with 69\% (Cornwall and Stringer, 2008), 79\% (Cornwall et al., 2013), and 80\% (Romero-Reveron, 2015) of cases attributed to this cause. The scalpel is by far the sharpest instrument students will use for dissection in anatomy laboratories. From the authors' perspective, widely accessible 'automatic' scalpel blade removal systems from clinical settings eliminate manual unloading of removable blades and have the potential to reduce sharps injuries. However, students still have to mount the blades manually onto the handles. A potential solution could be the use of disposable or reusable scalpels and retractable safety scalpels (Watt et al., 2010; Cornwall et al., 2013). Nonetheless, conclusive evidence on the efficacy of such devices is required in both clinical (Watt et al., 2010) and educational settings (Cornwall et al., 2013). The overall compliance with their use is also uncertain (Watt et al., 2008). It has been suggested that 'automatic' systems, such as the blade removers, are more effective interventions when compared to devices requiring activation by their user including safety scalpels (Watt et al., 2010). Another way of managing the risk from mounting blades is to have members of the academic or technical team pre-loads all handles, or ensuring 'safe' methods of blade mounting or removal are adhered to by students, such as the 'Hands together' method (Cornwall 2014).

\section{Splash Safety}

There were no documented splash injuries during the assessed five-year period, with RomeroReveron (2015) reporting two formalin splashes to the face over ten years and Cornwall et al. 
(2008) stating one splash injury to the face. Taking into consideration the reported rarity of such injuries in the context of dissection, the use of safety goggles as part of mandatory PPE for students is a highly debatable topic. In the setting of mortuaries, eye protection is recommended for all autopsies to protect workers (Burton, 2003). The Royal College of Surgeons of England also endorses protective eyewear during surgery (Davies et al., 2007). Hands-on dissection, especially of unembalmed cadavers, shares several similarities with both of these environments and it seems prudent to wear safety goggles. Underreporting of sharps and especially splash injuries also conceals the true scale of such incidents. A study from a similar institution in Scotland showed that $40 \%$ of undergraduate medical students who had sustained a contaminated sharps injury went on to report it (Varsou et al., 2009). Even less mucocutaneous exposures tend to be reported in clinical settings (Doebbeling et al., 2003). This may be partly due to these incidents not being perceived or even recognized as injuries or due to the complexity of the reporting process (Vose et al., 2009). Fears of embarrassment and potential disciplinary implications have also been cited as reasons (Choi et al., 2017). Basing the use of safety goggles around the infrequency of splash injuries is not a valid argument for not incorporating eyewear into PPE especially when considering the potential magnitude of their underreporting.

\section{Cost-Benefit Analysis}

The cost associated with dissection instruments, blade remover systems, and PPE is an important factor to take into account irrespective of who bears it, academic institutions or students, when considering to adopt alternative 'safer' devices. Certain items are essential for partaking in dissection classes including sharp instruments, such as scalpels, and PPE in the form of disposable gloves and laboratory coats. However, even for these categories of items, there are 
multiple choices available and hence different estimated price ranges (Table 4). For instance, a disposable metal scalpel blade excluding the reusable handle may range from $£ 0.08$ to $£ 0.30$, whereas a disposable retractable scalpel may be priced between $£ 1.50$ and $£ 6.00$ making this option comparatively more expensive even though it may be perceived as a 'safer' alternative to 'traditional' approaches in terms of mitigating the risk of injury. In terms of scalpel blade remover systems, these can be broadly divided into three categories: (1) individual blade devices either single use or reusable; (2) two-hand; and (3) one-hand systems (Table 4). The one-hand devices should be mounted on stationary points potentially minimize the risk of injury especially when used with slippery gloves following dissection, but this system is also a comparatively expensive option costing approximately $£ 20$ to $£ 25$ per unit. At the moment, there is lack of data directly comparing the different blade remover systems making it challenging to draw inferences regarding their safety.

From the authors' cost-benefit analysis, the non-branded options from medical equipment supplier companies were comparatively less expensive, but their specifications were not as detailed. The sterile options were also slightly more expensive when compared to the non-sterile equivalents. It is worth bearing in mind that all of the estimated prices do not include any of the associated costs incurred by cleaning, disposal or even staff time. The disposable devices also generate a substantially larger amount of waste some of which might require specialist disposal resulting in additional 'hidden' costs, but also placing a potential burden on the environment depending on the type of plastic used for the handles and whether it is biodegradable or recyclable. This is an area requiring further exploration, in the form of primary research studies, 
with the aim of compiling standardized guidelines for the use of recommended instruments and devices that would best suit the specialist environment of anatomy laboratories.

\section{Dissecting Experience}

A decreasing rate was noted as students progressed through their studies with a frequency rate of 0.692 in year one, 0.234 in year two and zero for year three per 1,000 student-hours. Similar trends have been observed with increasing year of study in the context of dissection for undergraduate medical students (Cornwall and Stringer, 2008; Cornwall et al., 2013). Specifically, Cornwall et al. reported a rate of 5.5 and 1.3 per 1,000 hours in second and third year medical students respectively (2013). However, as discussed earlier, the number of students allocated per cadaver and the number of students dissecting concurrently might be a potential confounder. The region being dissected might also contribute to this trend with an argument that completing a larger gross dissection in the same time period as for smaller areas might increase the frequency of injuries. In the present study, dissection of the upper and lower limb had an injury rate of 0.772 per 1,000 student-hours with no documented cases for the head and neck region. Similarly, Cornwall et al. (2013) noted the highest injury rate to be associated with the upper and lower limbs (i.e., 5.5 per 1,000 hours; year two) and the least with the head and neck (i.e., 1.3 per 1,000 hours; year three). Students in the present study dissected all regions standing up supporting the notion that dissecting posture does not affect injury rates (Cornwall et al., 2013). From the above findings, it is evident that there is a complex relationship between year of study and the following factors: density of students per cadaver; region dissected; and increasing dissecting experience. 
Smith and Leggat (2004) reported that prevalence of sharps injuries was highest among third year nursing students. The same authors identified being a year three student as a significant risk factor for sharps injuries (Smith and Leggat, 2004). Nursing students have also been observed to experience the highest number of injuries in teaching hospitals (Hada et al., 2018). While nursing and medical curricula may not be directly comparable, these observations support the notion that experience might contribute to a reduced risk of injury in undergraduate settings. However, Sharew et al. (2017) found no statistically significant association between increased work experience and risk of sharps injury. Rampal et al. (2010) also reported no significant association between more years of work service and reduced frequency of sharp injury. Students dissect in a simulated and relatively 'safe' surgical environment, whereas qualified healthcare professionals undertake more complex manual tasks in higher-pressure environments with instruments being hidden or under-recognized that may partly explain the difference between undergraduate and postgraduate settings. Considering all of the above, there is a need to further elucidate with prospective studies the exact role experience plays in relation to injury rates.

\section{Safety Training}

Lack of sharps safety training is a recognized issue among healthcare professions. A study on sharps injuries among surgical residents revealed that $55.1 \%$ had received no sharps safety training (Alghamdi et al., 2018). Sharew et al. (2017) found that healthcare staff with no relevant training were 4.7 times more likely to suffer a sharps injury than those who were adequately trained. The authors feel that regular sharps training is essential in terms of instilling safety conscious behaviors in clinical or educational settings and hence reducing the risk of injury. Such training would be best delivered in a blended style, with face-to-face sessions and online 
refreshers, ideally integrated and tailored to the needs of each individual anatomy syllabus.

Adopting approaches from surgical environments or developing tailored peer-assessed

techniques in anatomy laboratories would also be beneficial in mitigate risks. For example, the 'hands together' method by Cornwall (2014) is an alternative low risk method for mounting and removing blades from scalpel handles that could potentially reduce injuries. However, the issue of compliance with such methods and even raising awareness of their existence remains an issue (Cornwall, 2014).

\section{Culture Shift}

There is a growing need for a culture shift in current safety behaviors and hence practices (Watt et al., 2008) that is not only limited to clinical settings, but also extends to anatomy laboratories as there are many similarities in the instruments, procedures and required attitudes. Like the operating theatre that is an environment of close cooperation (Vose et al., 2009), dissection in anatomy laboratories is very much analogous involving collaborative partnerships and clear communication among team members. Considering that $14.3 \%$ of injuries in the present study were caused by a colleague/peer, perhaps it is time to focus on non-technical skills (i.e., communication, situation awareness, teamwork, and interpersonal relationships) and how these relate to human factors in anatomy laboratories with the aim of developing tailored safety procedures. Anesthetists in operating theaters have adopted such workflows with great success by learning from the aviation industry (Toff, 2010). This type of universal evidence-based guidelines will help shape and standardized a culture change (Watt et al., 2008). A multidisciplinary consortium consisting of anatomists, human factors specialists, clinical staff and occupational health experts could inform the design and implementation of such guidelines. 


\section{Limitations}

Although there was a robust record keeping mechanism for injuries during the assessed period, minimizing the likelihood of missing information and recall bias, there was no standardized inhouse documentation prior to the introduction of the compulsory training program in 2013 . This prevented a direct comparison between pre- and post-training injury cases. The retrospective nature of the study also limited the authors from establishing a cause-effect relationship especially in determining the exact association between advancing dissecting experience or safety measures and frequency rate. In addition, the authors could not make any inferences in relation to the frequency rate and the demographics or the assessment performance of the study population due to the exclusion of all demographic and identifiable information during data collection. Finally, information was drawn from a single higher education institution and it should be generalized with caution. Multi-center prospective observational studies, following an ethnographic-style of research in anatomy laboratories, will allow educationalists to draw better cause-effect links on this topic. These will also eliminate issues related to secondary data analysis from archival information including potential underreporting of injuries that might have been perceived as not worth reporting in the present study (i.e., sharps injuries not drawing blood or minor splash injuries that might have been self-treated without a staff member being aware of such cases).

\section{CONCLUSION}

In this study, a frequency rate of 0.384 per 1,000 student-hours was noted in relation to sharps injuries taking place during hands-on dissection. This is comparatively lower when considering 
relevant published literature that has reported rates of less than 4 (Cornwall and Stringer, 2008) and 2.87 per 1,000 hours of dissection (Cornwall et al., 2013). The authors believe that possibly the following factors might have played a role in increasing safety and potentially influencing frequency rates: (1) use of a scalpel blade removal system mounted in several stationary points within the anatomy laboratory increasing its accessibility; (2) mandatory PPE policy including safety goggles; (3) density of students per cadaver especially with having only one student dissecting at any given time. A decreasing trend in the frequency rate was also observed with advancing year of study that might be linked to increasing dissecting experience or the surface area of the region being dissected with larger areas, such as the upper and lower limbs, being studied in earlier years. However, it is important to bear in mind that no causality inferences can be made about the above points, as data in this study and the published literature were collected retrospectively highlighting the need for prospective ethnographic-style research on this topic.

Overall, although the likelihood of injury during dissection in anatomy laboratories is relatively low, the authors feel that it is still vital to have appropriate protocols in place to maximize safety. Specifically, early familiarization with appropriate safety procedures alongside regular sharps training and robust safety measures, with practices borrowed from surgical settings or standardized techniques and recommended instruments/devices tailored to the needs of a dissection-based environment, will instill safety conscious behaviors and influence injury rates in anatomy laboratories. Ultimately, safety conscious behaviors will have to be part of a larger evidence-based culture shift in practice, but these will undoubtedly prepare vocational and science learners for their future clinical and research practice respectively. 


\section{ACKNOWLEDGEMENTS}

The authors would like to acknowledge Ms. Gillian Strugnell who developed and introduced the training videos. The authors declare no potential conflicts of interest. 


\section{NOTES ON CONTRIBUTORS}

JAKUB FOYTL, B.Sc., is a third-year medical student at the School of Medicine, Dentistry and Nursing, University of Glasgow, Glasgow, Scotland, UK. He is interested in surgery and safety practices in operating theaters.

FRASER CHISHOLM, B.Sc., is a prosector at the School of Medicine, University of St Andrews, North Haugh, St Andrews, Scotland, UK. He is responsible for maintaining the anatomical specimens as well as assisting in technical duties and his research interest is in safety practices in the dissecting room.

OURANIA VARSOU, B.Sc., M.B.Ch.B., Pg.Cert., Ph.D., Af.H.E.A, is a lecturer in anatomy at the School of Life Sciences, University of Glasgow, Glasgow, Scotland UK. She is teaching human anatomy to science and vocational learners from sub-honors to honors levels and her research interest includes the integration of novel technologies in anatomy teaching, educationrelated quality assurance processes, and incorporation of humanities in science/medical curricula. 


\section{LITERATURE CITED}

Alghamdi MS, Abbas MM, Shafei MO, Alali AM, Alshareef MA, Aljabri FA, Zaidi NH, Aljiffry MM. 2018. Sharps Injuries in the operative room among residents in surgical specialities: A cross-sectional study. Saudi Surg J 6:11-15.

ATSDR. 2014. Agency for Toxic Substances and Disease Registry. Medical management guidelines for formaldehyde (HCHO). Centers for Disease Control and Prevention, Atlanta, GA. URL: https://www.atsdr.cdc.gov/mmg/mmg.asp?id=216\&tid=39 [accessed 19 March 2019].

Burton JL. 2003. Health and safety at necropsy. J Clin Pathol 56:254-260.

Chalya PL, Seni J, Mushi MF, Mirambo MM, Jaka H, Rambau PF, Mabula JB, Kapesa A, Ngallaba SE, Massinde AN, Kalluvya SE. 2015. Needle-stick injuries and splash exposure among health-care workers at a tertiary care hospital in north-western Tanzania. Tanzania $\mathbf{J}$ Health Res 17:1-15.

Choi LY, Torres R, Syed S, Boyle S, Ata A, Beyer TD, Rosati C. 2017. Sharps and needlestick injuries among medical students, surgical residents, faculty, and operating room staff at a single academic institution. J Surg Educ 74:131-136.

Cornwall J. 2014. The "hands together" method of nonsterile scalpel blade mounting and removal. Anat Sci Educ 7:161-166. 
Cornwall J, Davies TM, Lees D. 2013. Student injuries in the dissecting room. Anat Sci Educ 6:404-409.

Cornwall J, Stringer MD. 2008. Physical injuries in the dissecting room. Clin Anat 21:82-85.

Davies CG, Khan MN, Ghauri AS, Ranaboldo CJ. 2007. Blood and body fluid splashes during surgery - The need for eye protection and masks. Ann R Coll Surg Engl 89:770-772.

Doebbeling BN, Vaughn TE, McCoy KD, Beekmann SE, Woolson RF, Ferguson KJ, Torner JC. 2003. Percutaneous injury, blood exposure, and adherence to standard precautions: Are hospitalbased health care providers still at risk? Clin Infect Dis 37:1006-1013.

Ghasemi A, Zhadiesi S. 2012. Normality tests for statistical analysis: A guide for nonstatisticians. Int J Endocrinol Metab 10:486-489.

Hada V, Saurabh K, Sharma A, Nag VL, Gadepalli RS, Maurya AK. 2018. Nursing students: A vulnerable health-care worker for needlesticks injuries in teaching hospitals. J Family Med Prim Care 7:717-720.

Hambridge K, Nichols A, Endacott R. 2016. The impact of sharps injuries on student nurses: A systematic review. Br J Nurs 25:1064-1071. 
HSE. 2018. Health and Safety Executive. Health and Social Care Services: Sharps injuries. Health and Social Executive, Bootle, Merseyside, UK. URL: http://www.hse.gov.uk/healthservices/needlesticks/ [accessed 20 March 2019].

Johnson JH. 2002. Importance of dissection in learning anatomy: Personal dissection versus peer teaching. Clin Anat 15:38-44.

Mansour AA 3rd, Even JL, Phillips S, Halpern JL. 2009. Eye protection in orthopaedic surgery: An in vitro study of various forms of eye protection and their effectiveness. J Bone Joint Surg Am 91:1050-1054,

NHS Employers. 2015. Managing the risks of sharps injuries. NHS Employers, Leeds, UK. URL: https://www.nhsemployers.org/case-studies-and-resources/2015/12/hswpg-sharpsguidance [accessed 19 March 2019].

Rampal L, Zakaria R, Sook LW, Zain AM. 2010. Needle stick and sharps injuries and factors associated among health care workers in a Malaysian hospital. Eur J Soc Sci 13:354-362.

Romero-Reveron R. 2015. Accidental injuries in the dissecting room. J Morphol Sci 32:12-15.

Sargent Jones L, Paulman LE, Thadani R, Terracio L. 2001. Medical student dissection of cadavers improves performance on practical exams but not on the NBME anatomy subject exam. Med Educ Online 6:4522. 
Sharew NT, Mulu GB, Habtewold TD, Gizachew KD. 2017. Occupational exposure to sharps injury among healthcare providers in Ethiopia regional hospitals. Ann Occup Environ Med 29:7.

Sharps Policy. 2019. School of Medicine - Sharps Policy. Version 2019. St Andrews, Scotland, UK: University of St Andrews School of Medicine. 3 p. URL: http://medhandbook.standrews.ac.uk/wp-content/uploads/2014/05/infrastructure_safety_sharps-policy.pdf [accessed 19 March 2019].

Shoja MM, Benninger B, Agutter P, Loukas M, Tubbs RS. 2012. A historical perspective: infection from cadaveric dissection from the $18^{\text {th }}$ to the $20^{\text {th }}$ centuries. Clin Anat $26: 154-160$.

Smith DR, Leggat PA. 2005. Needlestick and sharps injuries among nursing students. J Adv Nurs 51:449-455.

Sugand K, Abrahams P, Khurana A. 2010. The anatomy of anatomy: A review for its modernization. Anat Sci Educ 3:83-93.

Toff NJ. 2010. Human factors in anaesthesia: Lessons from aviation. Br J Anaesth 105:21-25.

Varsou O, Lemon JS, Dick FD. 2009. Sharps injuries among medical students. Occup Med (Lond) 59:509-511. 
Vose JG, McAdara-Berkowitz J. 2009. Reducing scalpel injuries in the operating room. AORN J 90:867-872.

Watt AM, Patkin M, Sinnott MJ, Black RJ, Maddern GJ. 2010. Scalpel safety in the operative setting: A systematic review. Surgery 147:198-106.

Watt AM, Patkin M, Sinnott MJ, Black RJ, Maddern GJ. 2008. Scalpel injuries in the operating theatre. BMJ 336:1031. 


\section{FIGURE LEGENDS}

Figure 1. Qlicksmart BladeFLASK (Swann-Morton Ltd., Sheffield, UK) single-handed scalpel blade removal system mounted in the anatomy laboratory. This device has pictorial step-by-step instructions, on its face plate, for the correct technique of removing scalpel blades along with information on appropriate disposal methods. These devices are mounted on several stationary points within the anatomy laboratory and typically one system is shared between two dissection tables. The technical staff regularly check these to ensure that they are functioning and that full devices are promptly replaced. 


\section{बे

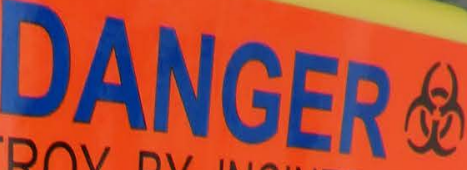 \\ DESTROY BY INCINERATION OR OTHER APPROVED METHODS}

CONTAMINATED SC
BladEFLASK

100 | Scalpel Blade Removal System
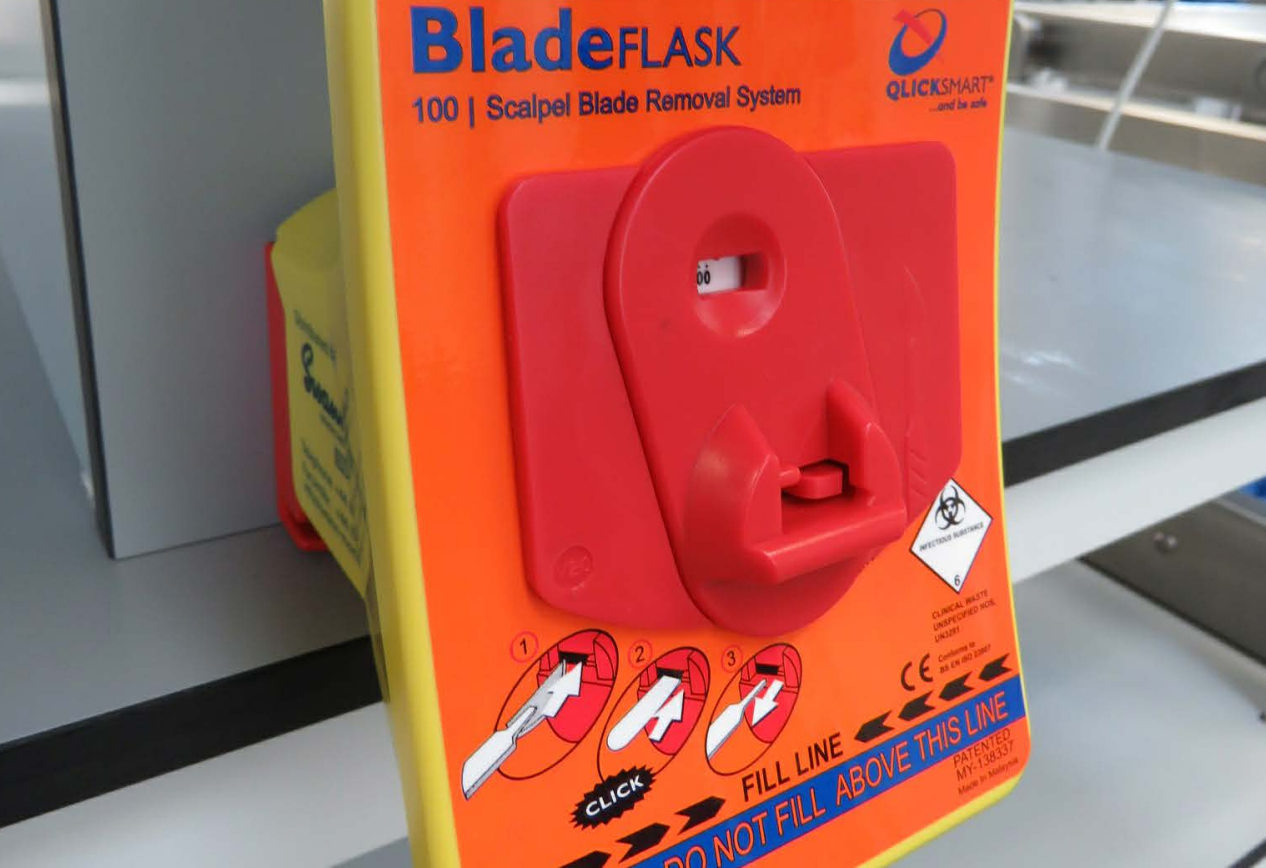
Table 1.

Structure, content and assessment of anatomy teaching per year of study and semester with contact hours

\begin{tabular}{|c|c|c|c|c|c|}
\hline $\begin{array}{l}\text { Year of } \\
\text { study }\end{array}$ & Semester & Body system* & $\begin{array}{l}\text { Dissected } \\
\text { regions }\end{array}$ & Contact hours** & $\begin{array}{l}\text { Summative } \\
\text { assessment } \\
\text { method } * * *^{*}\end{array}$ \\
\hline \multirow[t]{5}{*}{ First } & \multirow[t]{3}{*}{ First } & \multirow[t]{3}{*}{$\begin{array}{l}\text { Overview } \\
\text { covering all body } \\
\text { systems }\end{array}$} & No dissection & $\begin{array}{l}\text { Lectures: } 22 \\
\text { Laboratory: } 11 \\
\text { with prosections }\end{array}$ & 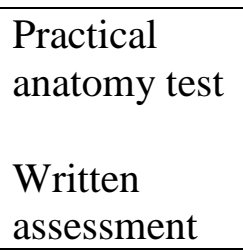 \\
\hline & & & $\begin{array}{l}\text { Back and } \\
\text { vertebral } \\
\text { column }\end{array}$ & $\begin{array}{l}\text { Lectures: } 2 \\
\text { Laboratory: } 5 \text { for } \\
\text { dissection }\end{array}$ & \multirow{2}{*}{$\begin{array}{l}\text { Practical } \\
\text { anatomy test } \\
\text { Written } \\
\text { assessment }\end{array}$} \\
\hline & & & & $\begin{array}{l}\text { Lectures: } 24 / 86 \\
\text { ( } 28 \% \text { of } \\
\text { curriculum) }\end{array}$ & \\
\hline & \multirow[t]{2}{*}{ Second } & \multirow[t]{2}{*}{$\begin{array}{l}\text { Musculoskeletal } \\
\text { system }\end{array}$} & \multirow[t]{2}{*}{$\begin{array}{l}\text { Upper and } \\
\text { lower limbs }\end{array}$} & $\begin{array}{l}\text { Lectures: } 15 \\
\text { Laboratory: } 20 \\
\text { for dissection and } \\
2 \text { for osteology }\end{array}$ & \multirow{2}{*}{$\begin{array}{l}\text { Practical } \\
\text { anatomy test } \\
\text { Written } \\
\text { assessment }\end{array}$} \\
\hline & & & & $\begin{array}{l}\text { Lectures: } 15 / 81 \\
\text { ( } 19 \% \text { of } \\
\text { curriculum) }\end{array}$ & \\
\hline \multirow[t]{4}{*}{ Second } & \multirow[t]{2}{*}{ First } & \multirow[t]{2}{*}{$\begin{array}{l}\text { Cardiorespiratory } \\
\text { system }\end{array}$} & \multirow[t]{2}{*}{ Thorax } & $\begin{array}{l}\text { Lectures: } 17 \\
\text { Laboratory: } 10 \\
\text { for dissection, } 1 \\
\text { for osteology and } \\
1 \text { with prosections }\end{array}$ & \multirow[t]{2}{*}{$\begin{array}{l}\text { Practical } \\
\text { anatomy test } \\
\text { Written } \\
\text { assessment }\end{array}$} \\
\hline & & & & $\begin{array}{l}\text { Lectures: } 17 / 91 \\
\text { (19\% of } \\
\text { curriculum) }\end{array}$ & \\
\hline & \multirow[t]{2}{*}{ Second } & \multirow[t]{2}{*}{$\begin{array}{l}\text { Gastrointestinal, } \\
\text { urinary and } \\
\text { reproductive } \\
\text { systems }\end{array}$} & \multirow[t]{2}{*}{$\begin{array}{l}\text { Abdomen } \\
\text { and pelvis }\end{array}$} & $\begin{array}{l}\text { Lectures: } 19 \\
\text { Laboratory: } 14 \\
\text { for dissection, } 1 \\
\text { for osteology and } \\
1 \text { with prosections }\end{array}$ & \multirow[t]{2}{*}{$\begin{array}{l}\text { Practical } \\
\text { anatomy test } \\
\text { Written } \\
\text { assessment }\end{array}$} \\
\hline & & & & $\begin{array}{l}\text { Lectures: } 19 / 90 \\
\text { ( } 21 \% \text { of } \\
\text { curriculum) }\end{array}$ & \\
\hline Third & First & $\begin{array}{l}\text { Endocrine and } \\
\text { Nervous system }\end{array}$ & $\begin{array}{l}\text { Head and } \\
\text { neck }\end{array}$ & $\begin{array}{l}\text { Lectures: } 22 \\
\text { Laboratory: } 14 \\
\text { for dissection, } 2 \\
\text { for osteology and } \\
2 \text { with anatomical } \\
\text { models }\end{array}$ & 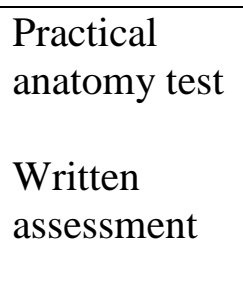 \\
\hline
\end{tabular}




\begin{tabular}{|l|l|l|l|l|l|}
\hline & & & $\begin{array}{l}\text { Lectures: 22/94 } \\
(23 \% \text { of } \\
\text { curriculum })\end{array}$ & \\
\cline { 2 - 6 } & Second & $\begin{array}{l}\text { Dissertation and } \\
\text { Applied Medical } \\
\text { Sciences }\end{array}$ & $\begin{array}{l}\text { No anatomy } \\
\text { teaching }\end{array}$ & $\begin{array}{l}\text { No anatomy } \\
\text { teaching }\end{array}$ & $\begin{array}{l}\text { No anatomy } \\
\text { assessment }\end{array}$ \\
\hline
\end{tabular}

*Each semester corresponds to a particular body system with the exception of the first semester in year one which is an overview of all body systems. Students learn the anatomy, physiology, pathophysiology, and clinical medicine for each system using a mixture of lectures, laboratory-based practicals, workshops, seminars, tutorials, and independent learning guided studies. Clinical with communication skills along with clinical placements run in parallel across all semesters including non-systems based topics such as ethics, research skills, and public health.

**On average, these are the contact hours for each student excluding multiple iterations of the same laboratory session for the assessed timeframe.

***Assessment completed at the end of each semester consisting of a practical anatomy test predominantly on prosections and a written component in the main assessment papers with anatomy multiple choice and short answer questions that are blueprinted according to the weighting of each teaching session.

Table 2.

Cumulative number of documented cases and frequency rate per year of study and semester from 2013 to 2018

\begin{tabular}{|c|c|c|c|c|}
\hline $\begin{array}{c}\text { Year of study } \\
\text { Semester } \\
\text { Dissected } \\
\text { Region }\end{array}$ & Teaching session & Cases (n) & Percent (\%) & $\begin{array}{c}\text { Frequency rate } \\
\text { per } 1,000 \\
\text { student-hours } \\
\text { of dissection* }\end{array}$ \\
\hline \multirow{4}{*}{$\begin{array}{l}\text { Year } 1 \\
\text { Semester } 1 \\
\text { Back }\end{array}$} & Introduction to dissection & 1 & 2.9 & \\
\hline & $\begin{array}{l}\text { Musculoskeletal features of } \\
\text { the vertebral column }\end{array}$ & 1 & 2.9 & \\
\hline & $\begin{array}{l}\text { Contents of the vertebral } \\
\text { canal }\end{array}$ & 1 & 2.9 & \\
\hline & Semester 1 total & 3 & 8.6 & 0.373 \\
\hline \multirow{10}{*}{$\begin{array}{l}\text { Year } 1 \\
\text { Semester } 2 \\
\text { Upper and } \\
\text { Lower Limb }\end{array}$} & $\begin{array}{l}\text { Gluteal region and back of } \\
\text { thigh }\end{array}$ & 3 & 8.6 & \\
\hline & Posterior leg compartment & 4 & 11.4 & \\
\hline & Anterior and lateral leg & 2 & 5.7 & \\
\hline & $\begin{array}{l}\text { Anterior and medial thigh } \\
\text { compartments }\end{array}$ & 1 & 2.9 & \\
\hline & Hip, knee and popliteal fossa & 4 & 11.4 & \\
\hline & $\begin{array}{l}\text { Scapular region and } \\
\text { glenohumeral joint }\end{array}$ & 6 & 17.1 & \\
\hline & Arm and elbow joints & 1 & 2.9 & \\
\hline & Forearm and carpus & 2 & 5.7 & \\
\hline & Hand & 2 & 5.7 & \\
\hline & Semester 2 total & 25 & 71.4 & 0.772 \\
\hline \multicolumn{2}{|l|}{ Year 1 total } & 28 & 80.0 & 0.692 \\
\hline
\end{tabular}




\begin{tabular}{|c|c|c|c|c|}
\hline \multirow{3}{*}{$\begin{array}{l}\text { Year } 2 \\
\text { Semester } 1 \\
\text { Thorax }\end{array}$} & $\begin{array}{l}\text { Removal of the anterior } \\
\text { thoracic wall }\end{array}$ & 2 & 5.7 & \multirow[b]{3}{*}{0.199} \\
\hline & Heart and pericardium & 1 & 2.9 & \\
\hline & Semester 1 total & 3 & 8.6 & \\
\hline \multirow{3}{*}{$\begin{array}{l}\text { Year } 2 \\
\text { Semester } 2 \\
\text { Abdomen and } \\
\text { Pelvis }\end{array}$} & $\begin{array}{l}\text { Abdominal wall and inguinal } \\
\text { region }\end{array}$ & 3 & 8.6 & \\
\hline & $\begin{array}{l}\text { Liver, gallbladder and } \\
\text { duodenum }\end{array}$ & 1 & 2.9 & \\
\hline & Semester 2 total & 4 & 11.4 & 0.234 \\
\hline \multicolumn{2}{|l|}{ Year 2 total } & 7 & 20.0 & 0.218 \\
\hline \multicolumn{2}{|l|}{ Year 3 total } & $\mathbf{0}$ & $\mathbf{0}$ & $\mathbf{0}$ \\
\hline & Overall Total & 35 & 100.0 & $\mathbf{0 . 3 8 4}$ \\
\hline
\end{tabular}

*Only the hands-on dissection time has been used to calculate the frequency rate.

Table 3.

Number of documented cases and frequency rate per academic year

\begin{tabular}{|l|c|c|c|c|}
\hline Academic year & $\begin{array}{c}\text { Total number } \\
\text { of students }\end{array}$ & Cases (n) & Percent (\%) & $\begin{array}{c}\text { Frequency rate per } \\
\mathbf{1 , 0 0 0} \text { student-hours } \\
\text { of dissection }\end{array}$ \\
\hline $\mathbf{2 0 1 7 - 1 8}$ & 454 & 6 & 17.1 & 0.309 \\
\hline $\mathbf{2 0 1 6 - 1 7}$ & 449 & 6 & 17.1 & 0.325 \\
\hline $\mathbf{2 0 1 5 - 1 6}$ & 460 & 10 & 28.6 & 0.552 \\
\hline $\mathbf{2 0 1 4 - 1 5}$ & 471 & 9 & 25.7 & 0.506 \\
\hline $\mathbf{2 0 1 3 - 1 4}$ & 461 & 4 & 11.4 & 0.230 \\
\hline Total & & $\mathbf{3 5}$ & 100.0 & \\
\hline
\end{tabular}

Table 4.

Cost-benefit analysis of different scalpel types, scalpel blade removal systems, and personal protective equipment

\begin{tabular}{|c|c|c|c|c|c|}
\hline Category & Manufacturer & Item & Cost $(\mathfrak{f})^{*}$ & Strengths $* *$ & Weaknesses** \\
\hline Scalpel types & Various & $\begin{array}{c}\text { Disposable } \\
\text { detachable } \\
\text { metal } \\
\text { scalpel } \\
\text { blade } \\
\text { (excluding } \\
\text { ceramic } \\
\text { blades) }\end{array}$ & $0.08-0.30$ & $\begin{array}{l}\text { - Comparatively } \\
\text { inexpensive } \\
\text { - Readily } \\
\text { available } \\
\text { - Replacement } \\
\text { blade always } \\
\text { sharp } \\
\text { - Different blade } \\
\text { shapes and sizes } \\
\text { available for the } \\
\text { same handle } \\
\text { - Withstand } \\
\text { pressure (in } \\
\text { conjunction } \\
\text { with stainless } \\
\text { steel handles) }\end{array}$ & $\begin{array}{l}\text { - Manual mounting } \\
\text { of blade } \\
\text { - Manual removal } \\
\text { of blade (when } \\
\text { used in isolation) } \\
\text { - Blade may detach } \\
\text { while dissecting } \\
\text { - Disposal cost of } \\
\text { used blades }\end{array}$ \\
\hline
\end{tabular}




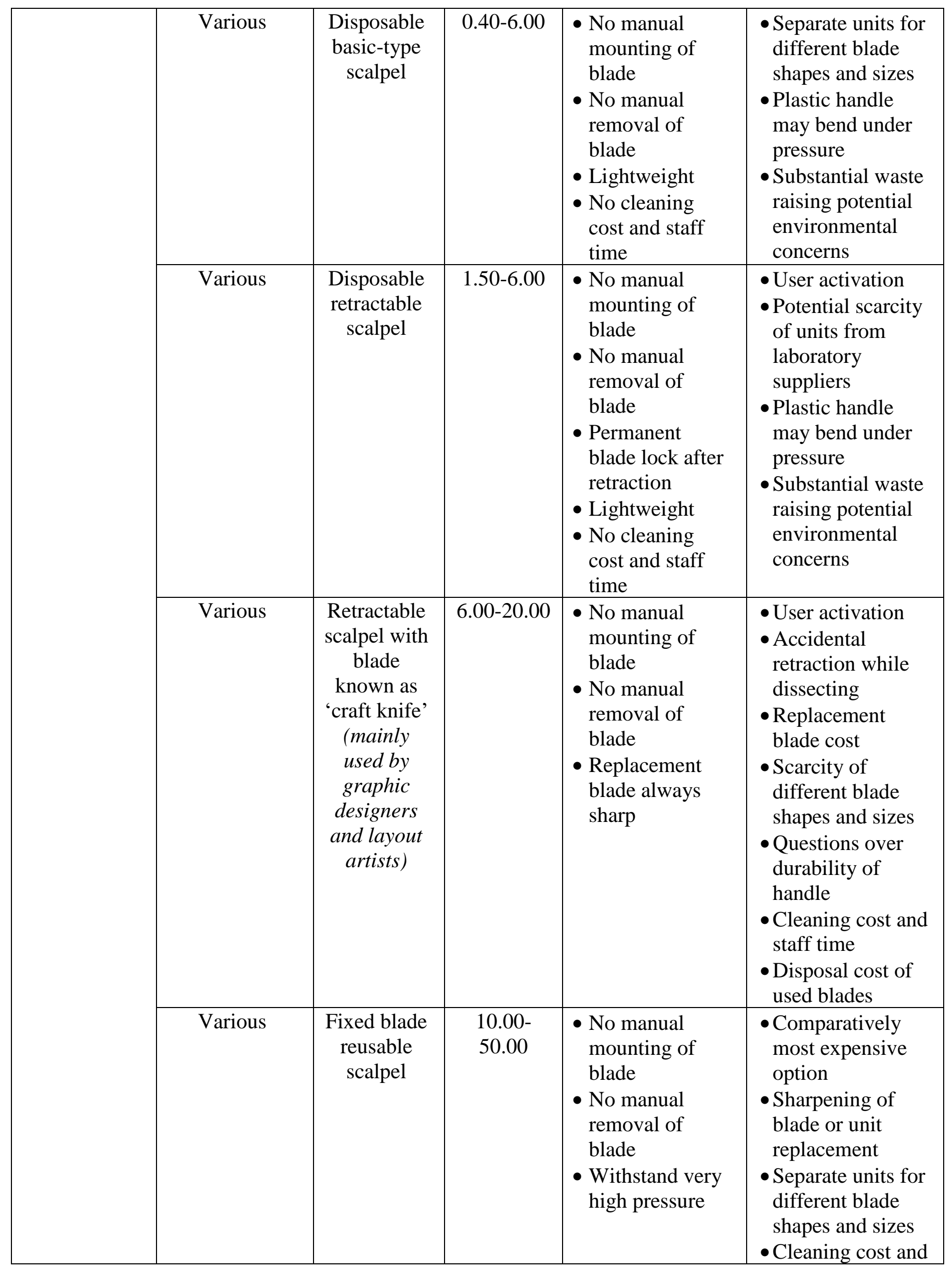




\begin{tabular}{|c|c|c|c|c|c|}
\hline & & & & & staff time \\
\hline \multirow[t]{4}{*}{$\begin{array}{l}\text { Blade } \\
\text { removal } \\
\text { devices and } \\
\text { systems }\end{array}$} & $\begin{array}{l}\text { Swann-Morton } \\
\text { Ltd., Sheffield, } \\
\text { UK }\end{array}$ & $\begin{array}{l}\text { Single use } \\
\text { individual } \\
\text { blade } \\
\text { devices } \\
\text { (e.g. 5505 } \\
\text { and 5502) }\end{array}$ & $0.20-0.40$ & $\begin{array}{l}\text { - Comparatively } \\
\text { inexpensive } \\
\text { - Comparatively } \\
\text { easy to use } \\
\text { - Available at } \\
\text { each dissection } \\
\text { table } \\
\text { - No downstream } \\
\text { injuries }\end{array}$ & $\begin{array}{l}\text { - Two-hand use } \\
\text { - Plastic may not } \\
\text { withstand } \\
\text { pressure } \\
\text { - Additional } \\
\text { disposal } \\
\text { equipment (e.g. } \\
\text { sharps container) } \\
\text { with associated } \\
\text { cost } \\
\text { - Substantial waste } \\
\text { raising potential } \\
\text { environmental } \\
\text { concerns }\end{array}$ \\
\hline & $\begin{array}{c}\text { Thermo } \\
\text { Scientific } \\
\text { Shandon Ltd., } \\
\text { Cambridge, } \\
\text { UK }\end{array}$ & $\begin{array}{l}\text { Reusable } \\
\text { individual } \\
\text { blade } \\
\text { devices }\end{array}$ & 30.00 & $\begin{array}{l}\text { - Durable } \\
\text { stainless steal } \\
\text { frame } \\
\text { - One-off } \\
\text { purchase } \\
\text { - Available at } \\
\text { each dissection } \\
\text { table } \\
\text { - No downstream } \\
\text { injuries }\end{array}$ & $\begin{array}{l}\text { - Two-hand use } \\
\text { - Comparatively } \\
\text { most expensive } \\
\text { option } \\
\text { - Requires } \\
\text { familiarization } \\
\text { for correct use } \\
\text { - Additional } \\
\text { disposal } \\
\text { equipment (e.g. } \\
\text { sharps container) } \\
\text { with associated } \\
\text { cost } \\
\text { - Cleaning cost and } \\
\text { staff time }\end{array}$ \\
\hline & $\begin{array}{c}\text { GF Health } \\
\text { Products Inc., } \\
\text { Atlanta, GA } \\
\text { Swann-Morton } \\
\text { Ltd., Sheffield, } \\
\text { UK } \\
\text { Non-branded } \\
\text { from medical } \\
\text { equipment } \\
\text { suppliers }\end{array}$ & $\begin{array}{l}\text { Two-hand } \\
\text { multiple } \\
\text { blades } \\
\text { system (e.g. } \\
\text { GF 2990) }\end{array}$ & $1.00-6.00$ & $\begin{array}{l}\text { - Comparatively } \\
\text { easy to use } \\
\text { - Available at } \\
\text { each dissection } \\
\text { table } \\
\text { - No downstream } \\
\text { injuries } \\
\text { - No cleaning } \\
\text { cost and staff } \\
\text { time }\end{array}$ & $\begin{array}{l}\text { - Two-hand use } \\
\text { - Disposal cost of } \\
\text { units }\end{array}$ \\
\hline & $\begin{array}{l}\text { Swann-Morton } \\
\text { Ltd., Sheffield, } \\
\text { UK }\end{array}$ & $\begin{array}{c}\text { Single-hand } \\
\text { multiple } \\
\text { blades } \\
\text { system (e.g. } \\
\text { Qlicksmart } \\
\text { BladeFLAS } \\
\text { K) }\end{array}$ & $\begin{array}{l}20.00- \\
25.00\end{array}$ & $\begin{array}{l}\text { - Single-hand use } \\
\text { - Wall-mounted } \\
\text { - No downstream } \\
\text { injuries } \\
\text { - No cleaning } \\
\text { cost and staff } \\
\text { time }\end{array}$ & $\begin{array}{l}\text { - Comparatively } \\
\text { second most } \\
\text { expensive option } \\
\text { - Disposal cost of } \\
\text { units }\end{array}$ \\
\hline
\end{tabular}




\begin{tabular}{|c|c|c|c|c|c|}
\hline \multirow[t]{4}{*}{ PPE } & Various & $\begin{array}{c}\text { Multiuse } \\
\text { fabric } \\
\text { laboratory } \\
\text { coat }\end{array}$ & $\begin{array}{c}20.00- \\
60.00\end{array}$ & $\begin{array}{l}\text { - Durable } \\
\text { - Long-lasting } \\
\text { - Multiuse }\end{array}$ & $\begin{array}{l}\text { - Comparatively } \\
\text { expensive } \\
\text { - Different coats } \\
\text { for different sizes } \\
\text { - Cleaning in terms } \\
\text { of cost and staff } \\
\text { time }\end{array}$ \\
\hline & Various & $\begin{array}{l}\text { Single use } \\
\text { protective } \\
\text { plastic } \\
\text { apron }\end{array}$ & $0.08-0.09$ & $\begin{array}{l}\text { - Limbs and neck } \\
\text { exposed } \\
\text { - Comparatively } \\
\text { inexpensive } \\
\text { - One size fits all }\end{array}$ & $\begin{array}{l}\text { - Prone to damage } \\
\text { - Substantial waste } \\
\text { raising potential } \\
\text { environmental } \\
\text { concerns }\end{array}$ \\
\hline & Various & $\begin{array}{c}\text { Disposable } \\
\text { nitrile } \\
\text { gloves }\end{array}$ & $0.07-0.08$ & & \\
\hline & Various & $\begin{array}{l}\text { Multiuse } \\
\text { safety } \\
\text { goggles }\end{array}$ & $3.00-10.00$ & & \\
\hline
\end{tabular}

*Approximate cost, in pound sterling (£), for each unit to be used solely as a guide to informing the discussion around different types of safety devices. Price estimates and ranges exclude the value-added tax (VAT) and the postage and packaging charges. The above estimates may also vary depending on manufacturer, geographic location, medical equipment suppliers, and currency exchange rates. **Strengths and weaknesses based on literature cited in this paper, personal experience, anecdotal data following discussions with colleagues, and information from online product catalogues.

PPE: Personal Protective Equipment 